\title{
TETRAPLOID WATERMELON PRODUCTION
}

\author{
ABD EL-WANIS, MONA M., A. A. EL-ZEINY AND A. E. ARAFA
}

Veg. Dep., Hort. Res. Inst., ARC, Dokki, Giza, Egypt.

(Manuscript received 14 September 2011)

\begin{abstract}
Tetraploids are desired to produce seedless fruits. In order to produce an autotetraploid population in watermelon (Citrullus lanatus Thunb) by colchicine. four treatment methods were examined ( dry seeds, soaking of germinated seeds and the meristem tip of the seedlings at the emergence of two true type leaves beside the control treatment ) to determine the best treatment for the induction of tetraploid plants. Autotetraploid plants were produced by all treatments with colchicines. meristem tip treatment at two true leaves stage proved to be the most effective in obtaining autotetraploids. In order to distinguish the induced colchicines tetraploid plants from the diploids, morphological change and techniques as number of chloroplast per guard cell and pollen grain diameter were considered and proved that these methods are suitable, quick and easy for identification to the ploidy level of watermelon cv. Sugar Baby. The chromosome scoring in watermelon plants was 22in plants diploid $(2 n=2 x=$ 22) and 44 in tetraploids $(2 n=4 x=44)$. Tetraploid produced plants with short stem length but dark green leaves with great amount of branches per plant and chlorophyll content compared to diploid plants. Less amount of fruits per plant, fruit weight, TSS and number of seeds per fruit were noticed in tetraploid plants as compared with diploid plants. The seeds of diploid were oblong whereas the tetraploids varied from oblong to round.
\end{abstract}

\section{INTRODUCTION}

Watermelon (Citrullus lanatus Thunb) is an important cucurbitaceous vegetable. Plant breeders induce polyploidy as an attempt to increase yield, improve qualities like fruit size or vigor, and to adapt crops to particular growing conditions and also found to be resistant to watermelon fruit blotch and nematodes (Montalvo \& Esnard, 1994, and Garret et. al., 1995). In watermelon, polyploidy is utilized to produce seedless fruits.

Seedless is an important and desirable breeding objective in horticultural crops. Seedless (triploid) watermelons are preferred by consumers because of high fruit quality, absence of seeds and sweeter than seed diploid cultivars (Marr \& Gast, 1991).

Seedless watermelons often are rare in the market place due to difficulties associated with obtaining new tetraploid breeding lines and poor germination of tetraploid seed (Mohr, 1986). 
Seedless watermelons are triploid $(3 x=33)$ and result from crossing a tetraploid ( $2 n=4 x=44)$ seed parent with a diploid $(2 n=22)$ pollen parent (Kihara, 1951, and Andrus et. al., 1971).

Traditionally, tetraploid breeding lines are obtained by applying an aqueous colchicine solution to the growing apex of diploid seedlings (Kihara, 1951) or soaking diploid seeds in colchicine solution. However, the frequency of tetraploids in treated population is low( less than 5\%) in most cases (Lower \& Johnson, 1969 , Andrus et. al., 1971).

Effective colchicine treatments have been reported for several crop plants like maize (Wan et. al., 1989), wheat (Zamani et. al., 2000), and Indian mustard (Prem, 2004).

Tetraploids can be detected by the direct method of counting chromosomes of cells under the microscope, and (or) by comparing stem, leaf, flower, and pollen size. On the other side, tetraploid plants usually have thicker leaves, slower growth and shorter stems than diploid control (Jacobs \&Yoder, 1989).

Tetraploid lines of watermelon can be identified by determining the density of guard cell chloroplasts from leaf epidermal peels (McCuistion \& Elmstron, 1993, Compton et. al., 1996). A popular method involves counting the number of chloroplasts in stomatal guard cells using a leaf peel under the microscope. However tetraploids have approximately $10-14$ chloroplasts in each side of the guard cell (20 - 28 total), whereas diploids have only $5-6$ in each side (10 - 12 total). The methods are useful for screening many plants for ploidy level in the seedling stage before transplanting to the main part the greenhouse field nursery for self- pollination (Compton \& Veilleux, 1991, Fassuliatis and Nelson, 1992, Cardi et. al., 1992).

We conducted this experiment in order to obtain tetraploid plants of citrllus (Citreous lanatus Thunb) using cholchicine treated diploid plants. Also the present study aimed to identify morphological and cytological trials, such as stomata and guard cell size, number of chromosomes and chloroplast per guard cell as well as pollen grain diameter whose performance depend on plant ploidy and can be used for indiect identification of diploids and tetraploids in citrullus plants.

\section{MATERIALS AND METHODS}

The present study was carried out during the two successive summer seasons of 2010 and 2011. The experiment consisted of the following four treatments for the induce tetraploidy in watermelon plants (Citrullus lanatus Thunb) $\mathrm{Cv}$.Sugar Baby treated with colchicine solution: 


\section{(1): Dry seed treatment}

One hundred seeds for each treatment, with three replicates, were soaked in colchicine solution ( Sigma - company, Egypt) at concentration of $0.05 \%(\mathrm{w} / \mathrm{v}, \mathrm{pH}$ $=6$ ) and $2 \%$ dimethyle sulfoxide (DMSO) and Tween 20 as a surfactant, at room temperature for the period of five days till germination. Then the treated seeds were rinsed thoroughly with distilled water and planted carefully on 5/1/2010 and 7/1/2011 (in the first and second seasons, respectively) in the seedling trays filled with a mixture of peatmoss and vermiculite at a ratio of $1: 1$ (v:v). In greenhouse under normal conditions at Kaha Station, Kalubia Governorate, which belong to Horticulture Research Institute, Giza, Egypt.

\section{(2): Soaking of germinated seeds treatment}

One hundred seeds for each treatment, with three replicates, were planted carefully on 5/1/2010 and 7/1/2011 (in the first and second seasons, respectively) in the seedling trays filled with a mixture of peatmoss and vermiculite at a ratio of $1: 1$ (v:v).in greenhouse under normal conditions at Kaha Stationt. After seed germination (at the emergency of cotyledon leaf stage) the seedlings were removed from the trays and soaked in colchicine solution (Sigma - company, Egypt) at concentration of $0.05 \%(\mathrm{w} / \mathrm{v}, \mathrm{pH}=6)$ and $2 \%$ dimethyle sulfoxide (DMSO) and Tween 20 as a surfactant, at room temperature for the period of 36 hours.

\section{(3): Meristem tip treatment of the seedlings}

One hundred seeds, with three replicates, were planted carefully on $5 / 1 / 2010$ and 7/1/2011 (in the first and second seasons, respectively) in the seedling trays filled with a mixture of peat moss and vermiculite at a ratio of $1: 1$ (v:v).in greenhouse under normal conditions at Kaha Station. The apical meristem of seedlings at the emergence of two true leaf stage was treated daily for fifteen days in the morning by dropping method using an aqueous solution of colchicine at concentration of $0.15 \%$ $(\mathrm{w} / \mathrm{v}, \mathrm{pH}=6)$ and $2 \%$ dimethyle sulfoxide (DMSO) and Tween 20 as a surfactant, at room temperature. Plants were covered with polyethylene plastic during treatment with the colchicine.

\section{(4)(Control): soaking of dry seeds in distilled water}

One hundred seeds, with three replicates, were soaked in distilled water for the period of 5 days till germination. After that the treated seeds were planted carefully on 5/1/2010 and 7/1/2011 (in the first and second seasons, respectively) in the seedling trays filled with a mixture of peat moss and vermiculite at a ratio of $1: 1$ $(v: v)$ in greenhouse under normal conditions at Kaha Station. 


\section{1- Ploidy analysis}

Section of diploid and tetraploid plants were done after one month on the basis of morphology, pollen grain size and followed by a section on size of stomata and guard cell measurements and finally chloroplast number in guard cells. The putative tetraploids were examined monthly later to validate ploidy stability.

\section{Chloroplast number per guard cells}

For study of the chloroplast number in the stomatal guard cells, samples of epidermal layer from abaxial side of diploid control plants and potential tetraploid plants 's leaves were obtained and this epidermal layer was stained with $1 \%$ lugol's iodine solution and observed by light microscope ( at $1000 \mathrm{x}$ magnification ) according to the method of Guima and Stotz, (2004). The stomata characteristics and chloroplast number were measured in middle leaves from each of the tested branches both in control and putative tetraploids.

On the lower epidermis 100 measurements of each of the parameters taken in control and putative metalloids, in three replications and each replication represented a different plant.

\section{Pollen grain diameter}

During flowering, another section was applied among treated plants on the basis of the pollen characteristics. From each of control and putative polyploidy plants,10 plants and from each plant a few anthers were sampled, fixed in 3:1 absolute ethanol: acetic acid solution for 24 hours and stored in $70 \%$ ethanol at $4^{\circ} \mathrm{C}$. For examination of pollen diameter in diploid and tetraploid plants. The anther should be macerated to release pollen grain. After staining with aceto - orceen $2 \%$ 1000x magnification) of 100 pollen grain from each of control plants and polyploidy plants was carried.

\section{Chromosome number determination}

Before polyploidy was induced, the chromosome number of the primary materials was determined in root tips of seedlings to confirm number of chromosomes in diploid material $(2 n=2 x=22)$. Root tips $(2-3 \mathrm{~mm})$ from actively growing roots were excised and pretreated in a saturated a-bromonaphthalene solution for 4 hours at $4^{0} \mathrm{C}$ to accumulate cells in metaphase. Then root tips were washed in distilled water for $10-15$ minutes and fixed over night in lewitski fixative at $4^{0} \mathrm{C}$ for $30-36$ hours. The fixative was prepared by mixing equal volume of $1 \%$ chromic acid and $4 \%$ formaldehyde ( $10 \%$ formalin) just before using. After rinsing twice with distilled water, root tips were hydrolyzed with $1 \mathrm{~N} \mathrm{NaoH}$ at $60{ }^{\circ} \mathrm{C}$ for 13 minutes and then rinsed in distilled water. Excess water was removed by blotting paper and the roots were stained for 16 hours in Aceto - Iron- Hematoxylin $4 \%$ at $30-32{ }^{\circ} \mathrm{C}$ according 
to the method of Agayev (2002). Then about $1 \mathrm{~mm}$ of the root tips were cut and transferred with a drop of $45 \%$ acetic acid on a slide for $3-5$ minutes. The preparations were observed with an optical microscope (at 1000x magnification). At least twenty meristems were analyzed.

\section{2- Morphological observations}

Watermelon seedlings were planted on15/3/2010 and 18/3/2011(in the first and second seasons, respectively), under green house at $50 \mathrm{~cm}$ apart between plants on one side of the middle of the rows. The plot area was $5 \mathrm{~m}^{2}$ including 2 rows each raw was $2.5 \mathrm{~m}$ in length and one $\mathrm{m}$ width. The experiment treatment was arranged in a randomized complete block design with three replicates. All cultural operations were similar to those practiced in commercial field production as recommended by Ministry of Agriculture, Egypt

At the end of growing season, fifteen plants of each plot were taken to determine:

1-Average length of the main stem.

2-number of branches per plant.

3- leaf area of the $7^{\text {th }}-9^{\text {th }}$ leaves from plant top using leaf area meter (LI-300COR - Lincolin).

4- Total leaf chlorophyll content in the leaf number 4 - 5 from plant top using chlorophyll meter (SPAD unit).

\section{3- Flowering and yield observation}

In addition of flowering time produced from both diploid and tetraploid plants other morphological characteristics such as petal diameter at their widest points (male and female flowers), collective diameter of all three flexuous anthers, ovary length and diameter were measured to examine their utility in predicting plant ploidy. Five progeny tetraploids (all treatments with colchicines) were compared to their respective diploids. Ten male and female flowers were examined per plant.

\section{Statistical analysis}

The statistical differences between of the control and autotetraploid plants were computed by the t- test and analysis of variance (ANOVA) by SPSS software.

\section{RESULTS AND DISCUSSION}

\section{1-_Ploidy analysis}

The percentage of survival plants are presented in Fig (1). Data show that all untreated plants with colchicine solution produced $100 \%$ of survival plants, while applying the meristem tip ( treat. 3) of watermelon plants with colchicine solution gave 25 and $23 \%$ of survival followed, in decreasing order , by treat.2 (20 and $19 \%$ ) and treat. 1 (10 and $9.3 \%$ ) in the first and second seasons, respectively. In 
comprehensive review of ploidy manipulation in fruit crops by colchicine treatment states that if the solution is too concentrated or the duration is too long, a high proportion of the meristems will be killed (Oiyama, and Okudai , 1986).

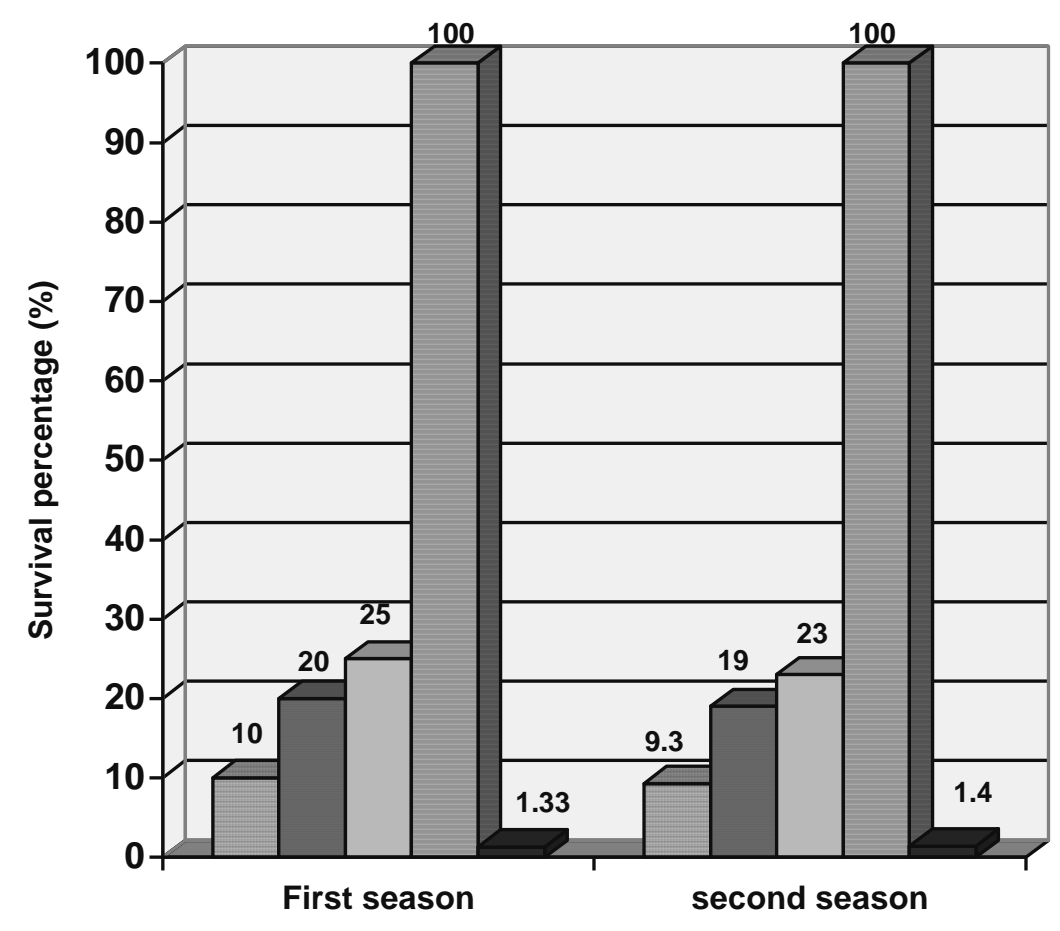

$\square$ Treat. $1 \square$ Treat. $2 \square$ Treat. $3 \square$ Treat. $4 \square$ L.S.D at 5\%

Fig. 1. Survival percentage of watermelon plants as affect by colchicine treatments.

Data about the percentages of diploid seedlings converted into tetraploids are presented for all treatments in Fig. (2). Data indicate that all the methods of colchicine treatments produced polyploids plant but the percentage of polyploid production differed according to the method of treatment However the meristem tip treatment of seedlings produced the highest percentage of tetraploids, on the contrary, soaking germinated seeds gave the lowest percentage. For the effective induction of tetraploidy in plants with colchicine treatment, the concentration of the chemical, duration and method of treatment are the most important factors (Sanford, 1983).. It was also reported that the role of application time and concentration of colchicines in the process of polyploidy plants obtained is significant. It was pointed that the duration and concentration of the colchicines differed with the plant growth period and the treated part (Tulany and Unal, 2010). 


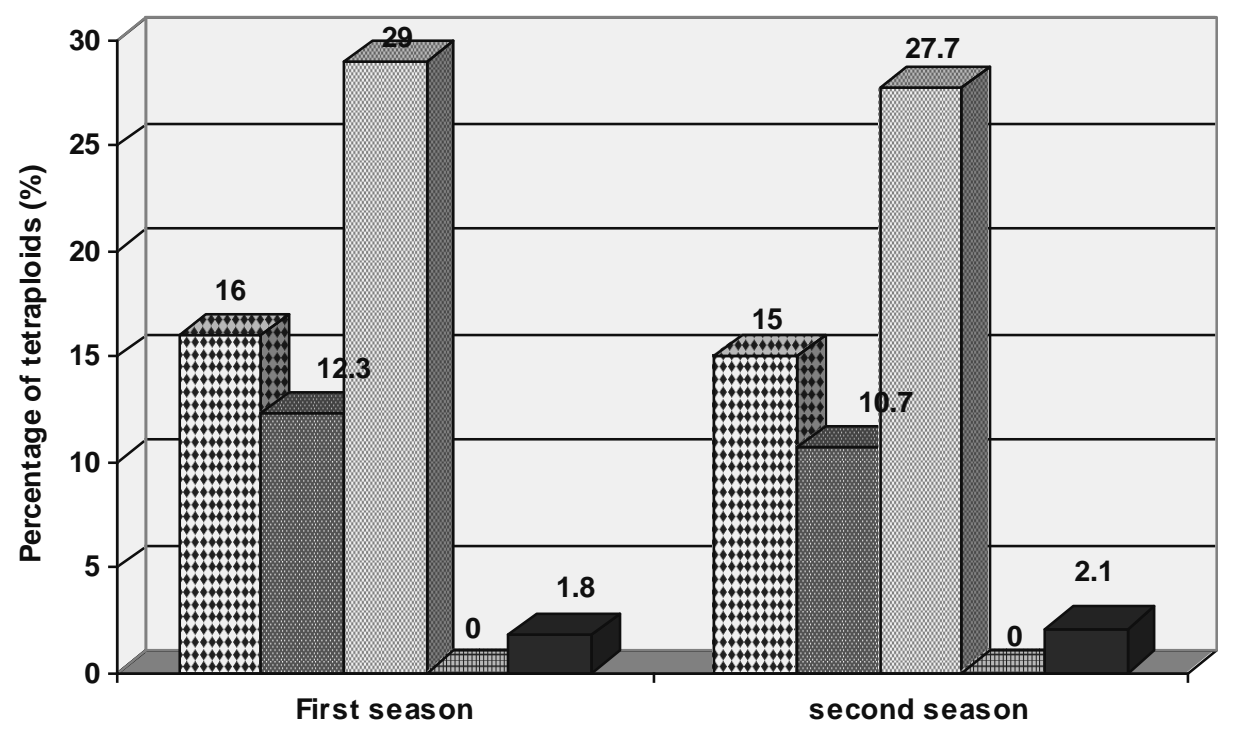

$\varpi$ Treat.1 $\square$ Treat.2 $\square$ Treat.3 $\mathbb{m}$ Treat.4 $\square$ L.S.D at 5\%

Fig. 2. Percentage of tetraploid production in watermelon plants as affect by colchicine treatments.

Concerning the number of chloroplasts and pollen grain diameter obtained from both diploid or tetraploid plants, data in Figs ( 3 A and B) and Figs (4 A and B) showed that all tetraploid plants (all cholchicine treatments) produced more number of chloroplasts and diameter of pollen grain than the diploid plants (control).On the other side, the number of chloroplast produced and the diameter of pollen grain from tetraploid plants differed among colchicine treatments. The meristem tip treatment (treat. 3) with colchicine showed the highest number of chloroplast and diameter of pollen grain in the two seasons under investigation compared with other treatments. In many of plant species, there are correlations between ploidy level and cytogenetic characteristics such as chloroplast number in guard cells, pollen grain diameter, however the number of chloroplast in guard cells and pollen grain diameter seemed to be reliable for the estimation of ploidy level. 
( Abak et. al., 1998 , McCuistion and Elmstrom, 1993).

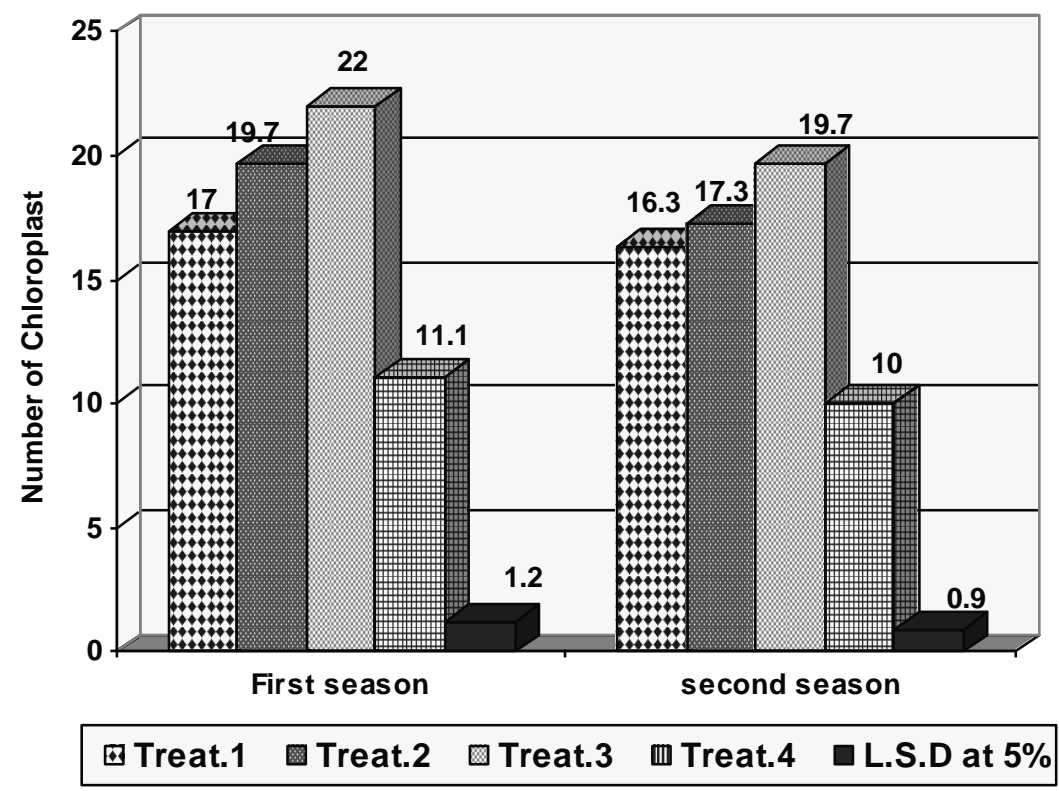

Fig. (3 A). Number of chloroplast in guard cells of watermelon plants as affected by colchicine treatments.
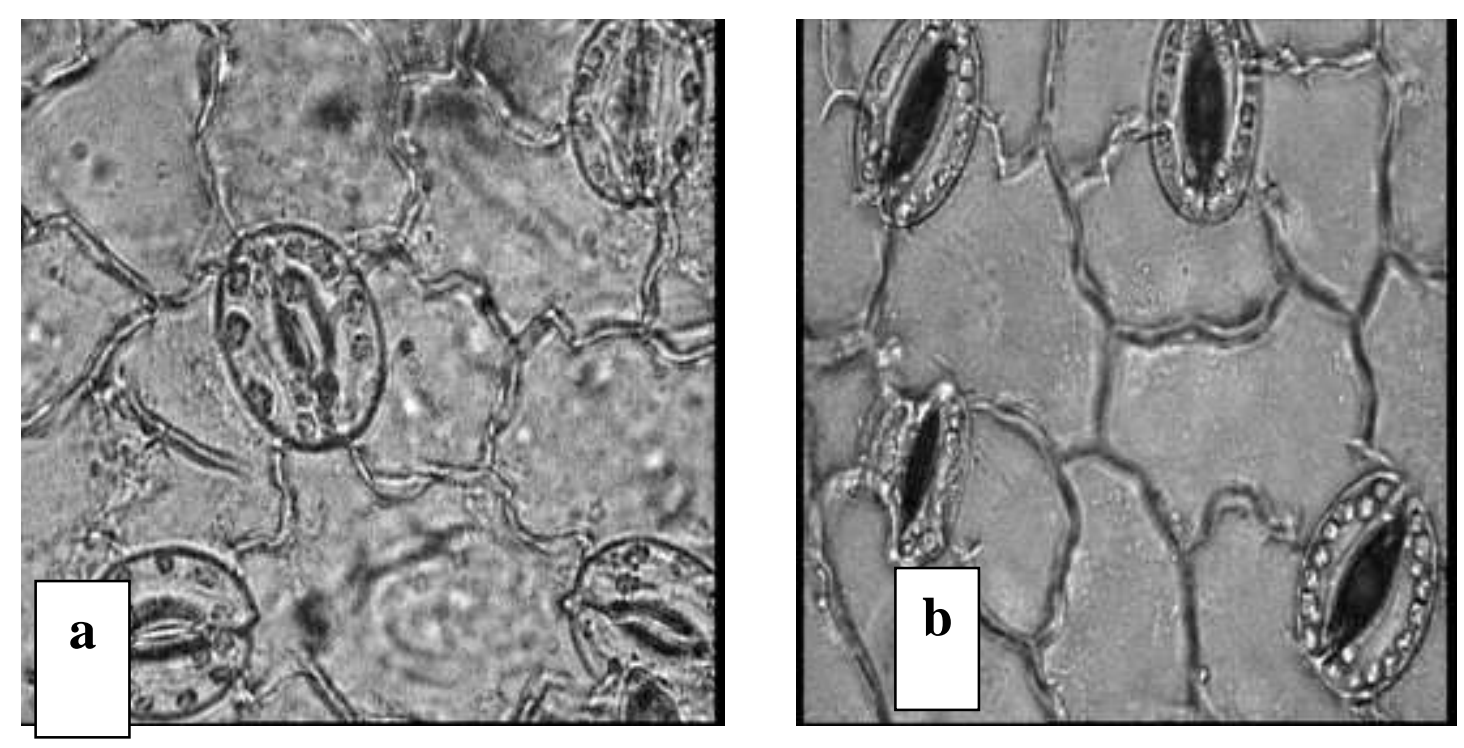

Fig. (3 B). Difference in chloroplasts number in guard cell between diploid (a) and tetraploid (b) ( $\times 4$ ) of watermelon plants. 


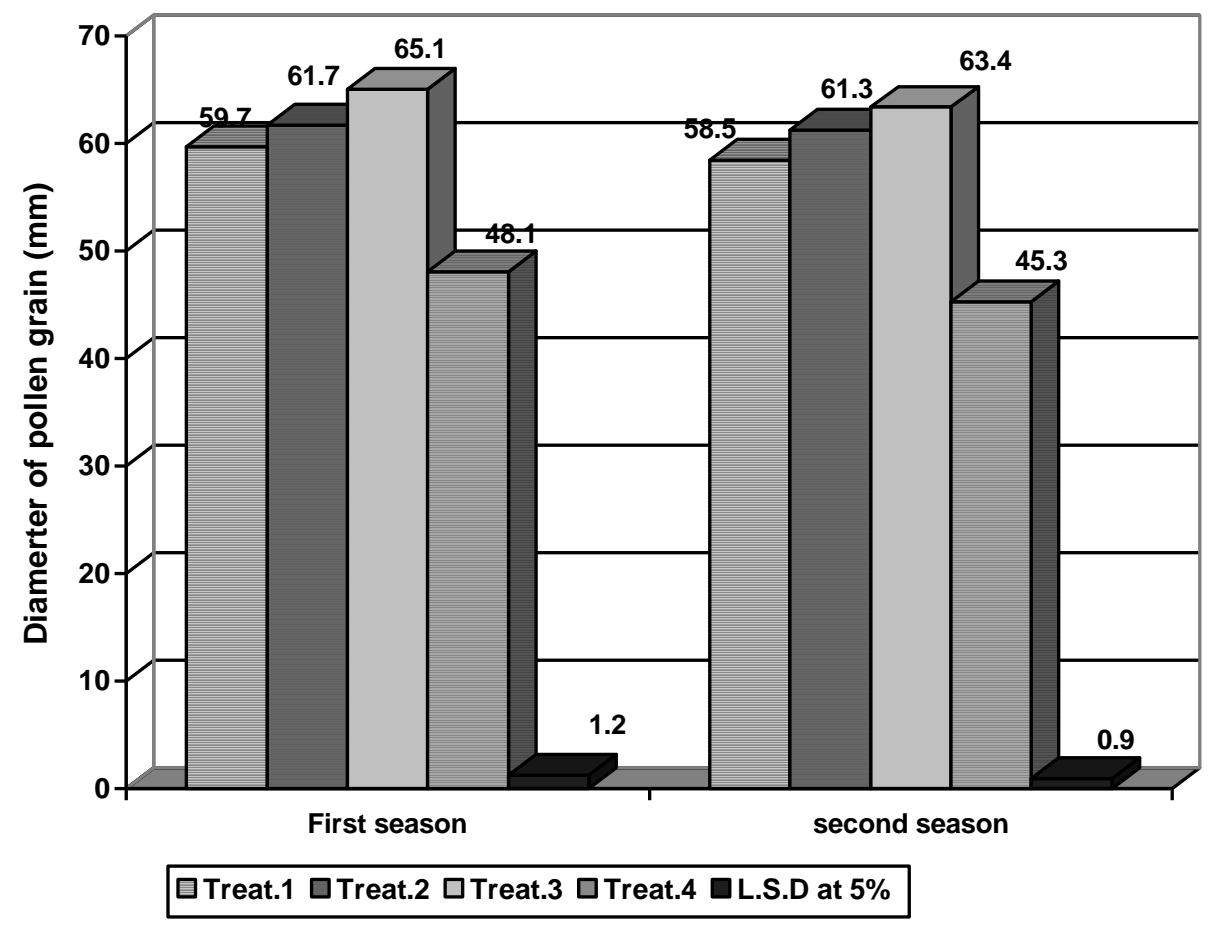

Fig. (4 A). Pollen grain diameter produced from diploid (control) and tetraploid watermelon plants as affected by colchine treatments.
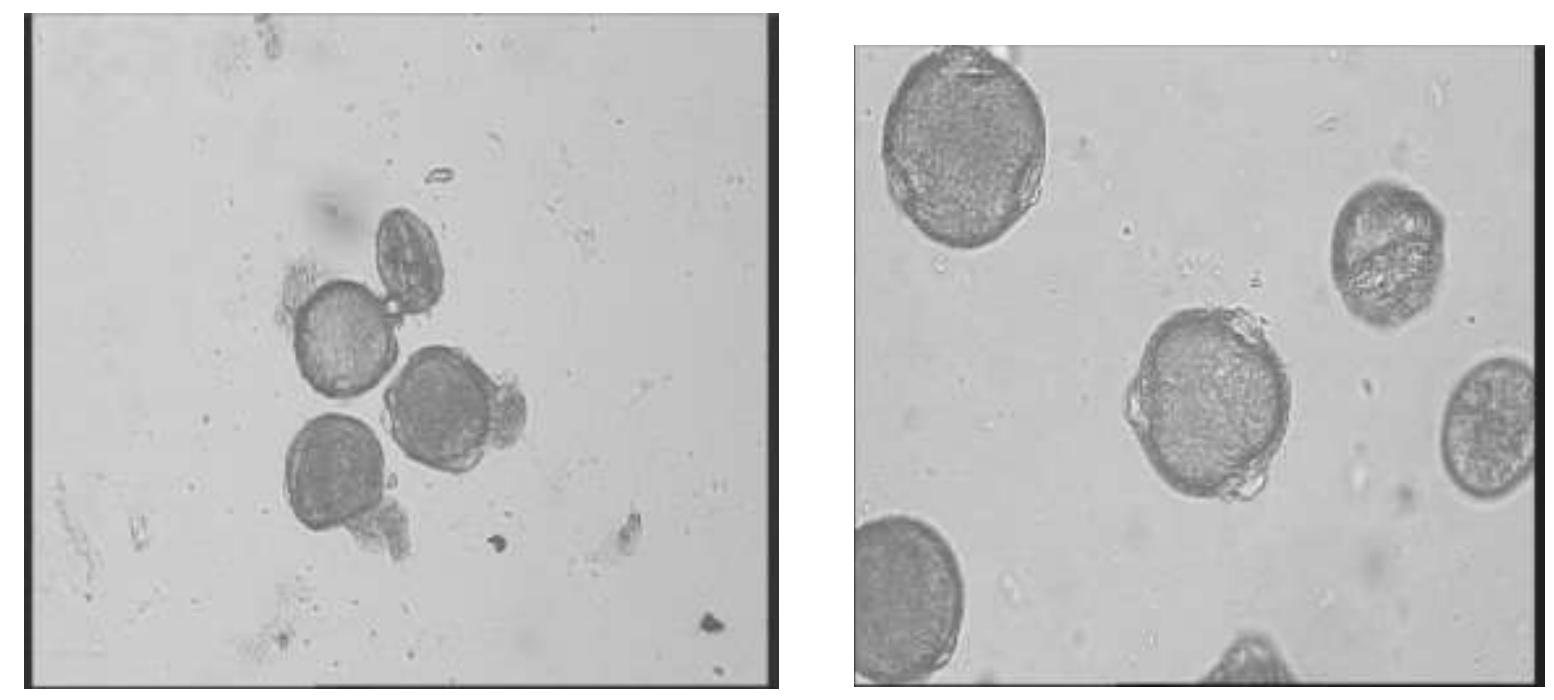

Fig. (4 B). Pollen grain diameter produced from diploid(a) and tetraploid(b) watermelon plants as affected by colchicine treatments ( $x 4)$. 
The results of chromosome scoring in watermelon plants (Fig.5) show that diploid having $2 n=2 x=22$ and tetraploids having $2 n=4 x=44$. Same results were reported by Muhammad et al. (2005) on watermelon plants.
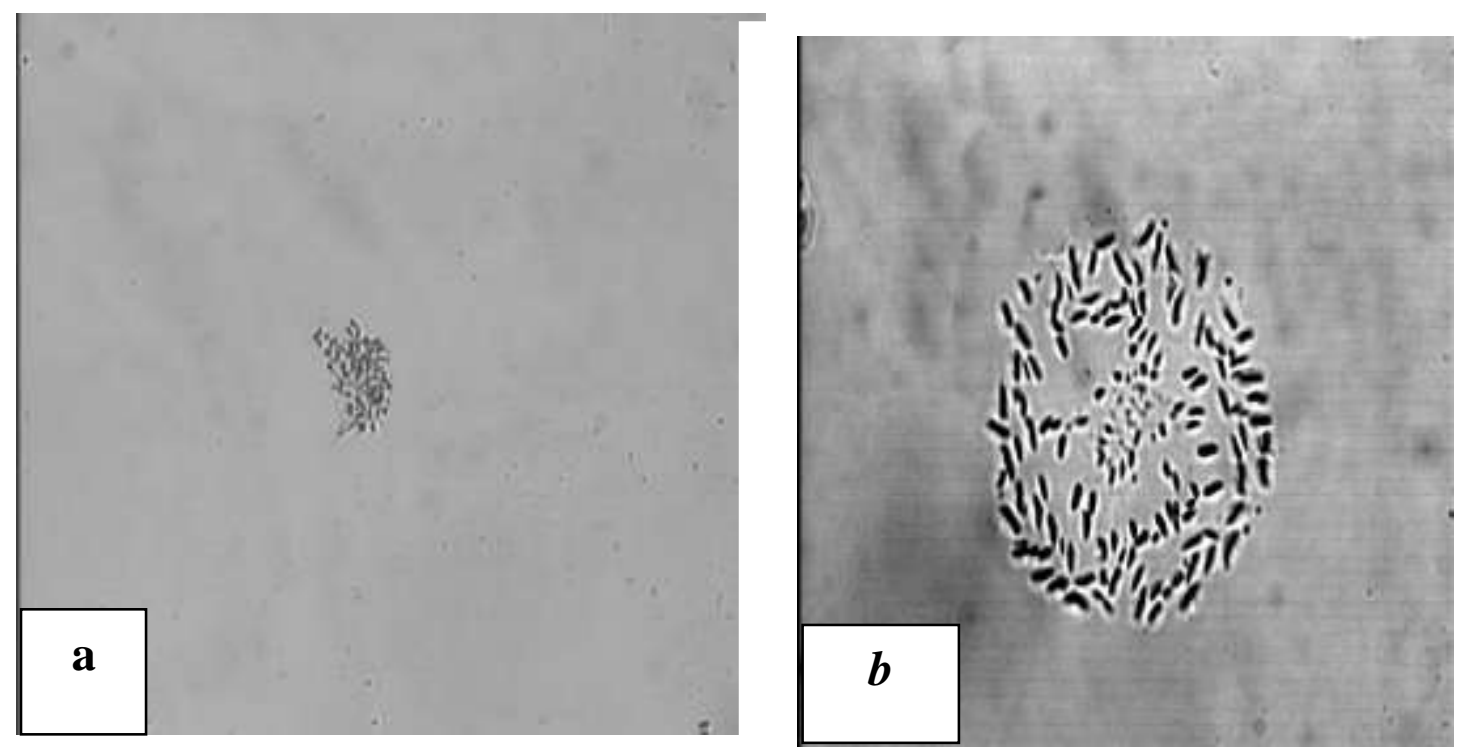

Fig. (5). Estimate of chromosome number in diploid (a) $(2 n=22)$ and tetaploidd (b) ( $2 n=44)(X 4)$ of watermelon plants .

\section{2- Morphological observations}

According to the morphological determination, Table (1) it could be concluded that there were that morphological differences between the diploid and tetraploid plants. The leaves of the tetraploid plants showed more thickness than diploid plants .On the other hand, tetraploids plants characterized with short stem length and more number of branches compared to diploid plants. The slower stem growth rate in tetraploids could be attributed to the reduced rate of cell division due to less growth hormones (Avery and Pottorf, 1945) and the low activity of metabolites in tetraploids ( Joshi and Verma , 2004).

On the contrary, data about leaf area indicate that tetraploid plant leaf area was wider than diploid plants. Same results have been reported by several investigators (Bhiravamurty and Rethy, 1984, Chakraborti et al., 1998, Joshi and Verma, 2004).

Darker leaves in tetraploids plants were noticed and contain more chlorophyll than diploid plants as presented in Table (1). Jaskani et al. (2005) reported also that tertraploid watermelon plants contain more chlorophyll than diploid plants. 
It could be concluded that the tetraploid plants of watermelon via colchicines treatments were characterized with short stem growth, more number of shoots beside leaves having dark green colour, greater amount of chlorophyll content and higher area compared to diploid results.

Table 1. Effect of colchicine treatments on the morphogenetic characters of watermelon plants.

\begin{tabular}{|c|c|c|c|c|c|c|c|c|}
\hline & \multicolumn{2}{|c|}{$\begin{array}{c}\text { Stem length } \\
(\mathrm{cm})\end{array}$} & \multicolumn{2}{c|}{$\begin{array}{c}\text { No. of branches } \\
\text { Per plant }\end{array}$} & \multicolumn{2}{|c|}{$\begin{array}{c}\text { Leaf area } \\
\left(\mathrm{cm}^{2}\right)\end{array}$} & \multicolumn{2}{|c|}{$\begin{array}{c}\text { Total leaf chlorophyll } \\
\text { (SPAD) }\end{array}$} \\
\cline { 2 - 9 } Treatments & $\begin{array}{c}\text { First } \\
\text { season }\end{array}$ & $\begin{array}{c}\text { Second } \\
\text { season }\end{array}$ & $\begin{array}{c}\text { First } \\
\text { season }\end{array}$ & $\begin{array}{c}\text { Second } \\
\text { season }\end{array}$ & $\begin{array}{c}\text { First } \\
\text { season }\end{array}$ & $\begin{array}{c}\text { Second } \\
\text { season }\end{array}$ & $\begin{array}{c}\text { First } \\
\text { season }\end{array}$ & $\begin{array}{c}\text { Second } \\
\text { season }\end{array}$ \\
\hline Treat. 1 & 100.50 & 99.00 & 10.80 & 10.30 & 135.30 & 131.30 & 51.30 & 50.00 \\
\hline Treat. 2 & 114.30 & 110.70 & 10.00 & 9.30 & 139.70 & 138.30 & 53.30 & 51.00 \\
\hline Treat. 3 & 129.70 & 125.70 & 8.00 & 7.30 & 145.00 & 141.30 & 56.00 & 55.30 \\
\hline Treat. 4 & 144.70 & 140.00 & 5.20 & 4.90 & 117.00 & 115.00 & 60.30 & 59.00 \\
\hline L.S.D. at 5\% & 1.21 & 2.60 & 1.01 & 0.93 & 1.40 & 1.90 & 0.95 & 1.52 \\
\hline
\end{tabular}

\section{3- Flowering and yield observation}

Data presented in Table (2) indicate that flower observations were good indicator of plant tetraploid whereas both male and female flowers were greater for tetraploid plants compared to diploids. On the other side, there was differences in petal diameter among tetraploid plants however, petal diameter of female flowers were greater than male flowers as shown in Table (2). Data also deduce that no differences were observed between treatments under investigations. Same results wee reported by in watermelon.

Table 2. Morphological characteristics of flowers from diploid and tetraploid watermelon plants as affect by colchicines treatments

\begin{tabular}{|c|c|c|c|c|c|c|c|c|c|c|}
\hline \multirow{3}{*}{ Treatments } & \multicolumn{6}{|c|}{ Female flowers } & \multicolumn{4}{|c|}{ Male flowers } \\
\hline & \multicolumn{2}{|c|}{$\begin{array}{l}\text { Petal diameter } \\
(\mathrm{mm})\end{array}$} & \multicolumn{2}{|c|}{$\begin{array}{l}\text { Ovary length } \\
(\mathrm{mm}\end{array}$} & \multicolumn{2}{|c|}{$\begin{array}{l}\text { Ovary diameter } \\
(\mathrm{mm})\end{array}$} & \multicolumn{2}{|c|}{$\begin{array}{c}\text { Petal diameter } \\
(\mathrm{mm})\end{array}$} & \multicolumn{2}{|c|}{$\begin{array}{c}\text { Anther diameter } \\
(\mathrm{mm})\end{array}$} \\
\hline & $\begin{array}{c}\text { First } \\
\text { season }\end{array}$ & $\begin{array}{l}\text { Second } \\
\text { season }\end{array}$ & $\begin{array}{c}\text { First } \\
\text { season }\end{array}$ & $\begin{array}{l}\text { Second } \\
\text { season }\end{array}$ & $\begin{array}{c}\text { First } \\
\text { season }\end{array}$ & $\begin{array}{l}\text { Second } \\
\text { season }\end{array}$ & $\begin{array}{c}\text { First } \\
\text { season }\end{array}$ & $\begin{array}{l}\text { Second } \\
\text { season }\end{array}$ & $\begin{array}{c}\text { First } \\
\text { season }\end{array}$ & $\begin{array}{l}\text { Second } \\
\text { season }\end{array}$ \\
\hline Treat. 1 & 38.10 & 38.00 & 18.60 & 18.00 & 10.20 & 10.00 & 23.00 & 22.50 & 7.00 & 6.80 \\
\hline Treat. 2 & 38.30 & 37.80 & 19.00 & 18.60 & 10.60 & 10.40 & 24.10 & 23.10 & 7.20 & 7.00 \\
\hline Treat. 3 & 38.90 & 38.40 & 19.20 & 18.90 & 10.80 & 10.60 & 24.20 & 24.00 & 7.30 & 7.20 \\
\hline Treat. 4 & 29.10 & 28.80 & 23.00 & 22.00 & 7.90 & 7.40 & 22.80 & 22.30 & 5.90 & 5.50 \\
\hline $\begin{array}{c}\text { L.S.D. at } \\
5 \%\end{array}$ & 1.10 & 1.20 & 1.20 & 0.80 & 0.65 & 0.41 & 1.30 & 1.20 & 0.23 & 0.11 \\
\hline
\end{tabular}


Concerning of physical characteristics of fruits obtained from diploid and tetraploid plants, data in Table (3) revealed that tetraploid plants produced fewer number of fruits per plant and the obtained fruits were smaller with fewer seed number and lower total soluble solid percent (Fig 6 A) than their diploids (control). Similar researches have been observed among tetraploid plants obtained from diploids watermelon treated with colchicines (Kihara, 1951). On the other side, differences in seed morphology of diploid and tetraploid wee noticed. The seeds of diploid were oblong whereas those of the tetraploids varied from oblong to round. Tetraploids had a coarse appearance with increase in seed length, width and thickness as noticed in Fig (6 B). Our results were in agreement with those obtained with Muhammed et al. 2005 on watermelon plants.

Table 3. Effect of colchicines treatments on the fruit physical characters of watermelon plants.

\begin{tabular}{|c|c|c|c|c|c|c|c|c|}
\hline & \multicolumn{2}{|c|}{ Number of fruits } & \multicolumn{2}{|c|}{$\begin{array}{c}\text { Average weight } \\
\text { of fruit }(\mathrm{kg})\end{array}$} & \multicolumn{2}{|c|}{$\begin{array}{c}\text { Total soluble } \\
\text { solid }\end{array}$} & \multicolumn{2}{|c|}{$\begin{array}{c}\text { Number of } \\
\text { seeds per fruit }\end{array}$} \\
\cline { 2 - 9 } Treatments & $\begin{array}{c}\text { First } \\
\text { season }\end{array}$ & $\begin{array}{c}\text { Second } \\
\text { season }\end{array}$ & $\begin{array}{c}\text { First } \\
\text { season }\end{array}$ & $\begin{array}{c}\text { Second } \\
\text { season }\end{array}$ & $\begin{array}{c}\text { First } \\
\text { season }\end{array}$ & $\begin{array}{c}\text { Second } \\
\text { season }\end{array}$ & $\begin{array}{c}\text { First } \\
\text { season }\end{array}$ & $\begin{array}{c}\text { Second } \\
\text { season }\end{array}$ \\
\hline Treat. 1 & 1.97 & 1.60 & 0.90 & 0.70 & 8.30 & 8.10 & 282.00 & 279.00 \\
\hline Treat. 2 & 2.00 & 1.70 & 1.30 & 1.10 & 9.10 & 9.20 & 307.00 & 300.00 \\
\hline Treat. 3 & 2.30 & 2.00 & 2.30 & 2.00 & 9.50 & 9.40 & 400.00 & 389.00 \\
\hline Treat. 4 & 4.20 & 4.00 & 3.50 & 3.30 & 12.50 & 12.10 & 945.00 & 907.00 \\
\hline L.S.D. at & 0.11 & 0.9 & 0.15 & 0.10 & 0.24 & 0.22 & 1.15 & 2.10 \\
\hline $5 \%$
\end{tabular}



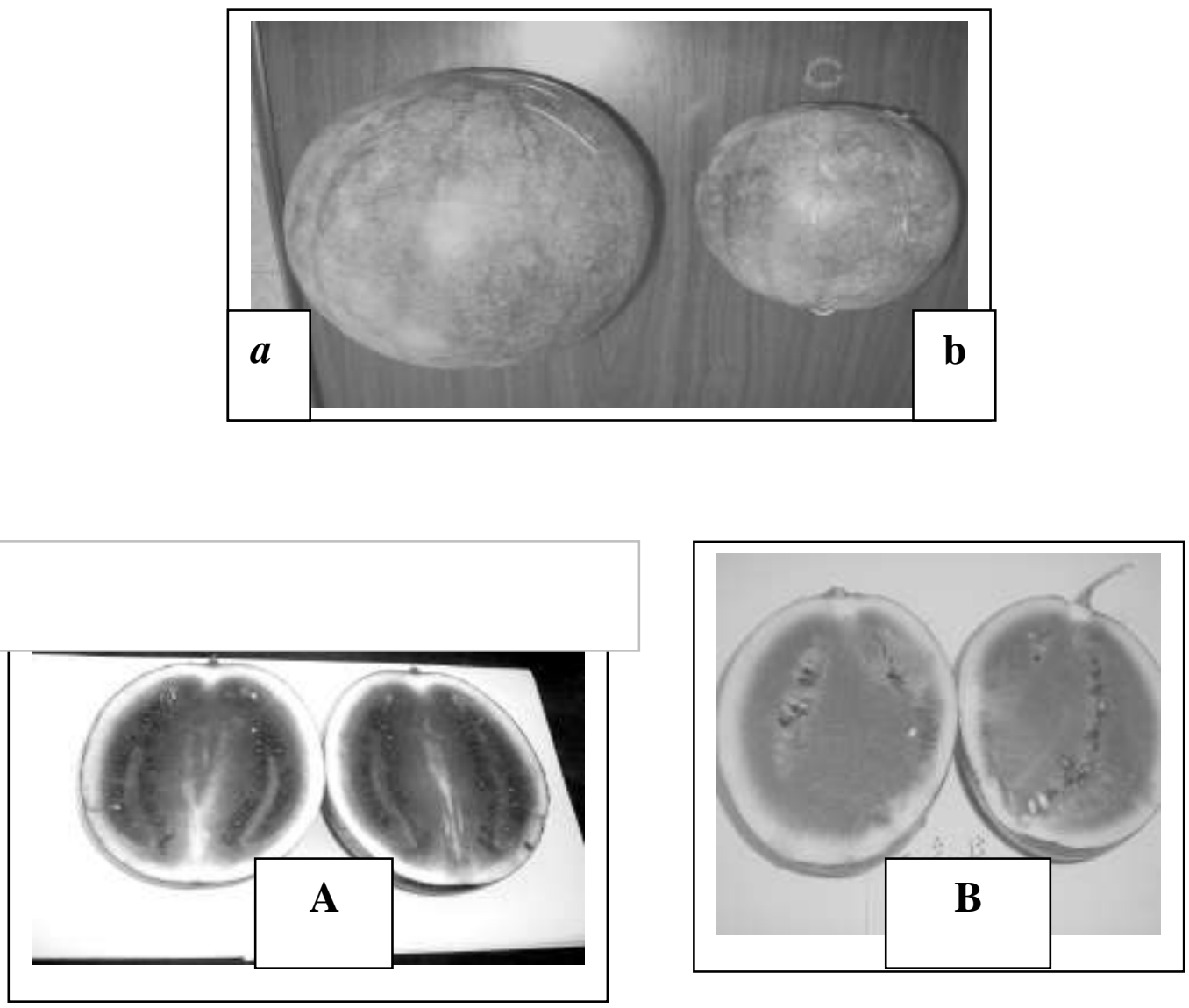

Fig (6 A). Different fruit weight and seed number obtained from diploid (a) and tetraploid (b) watermelon plants

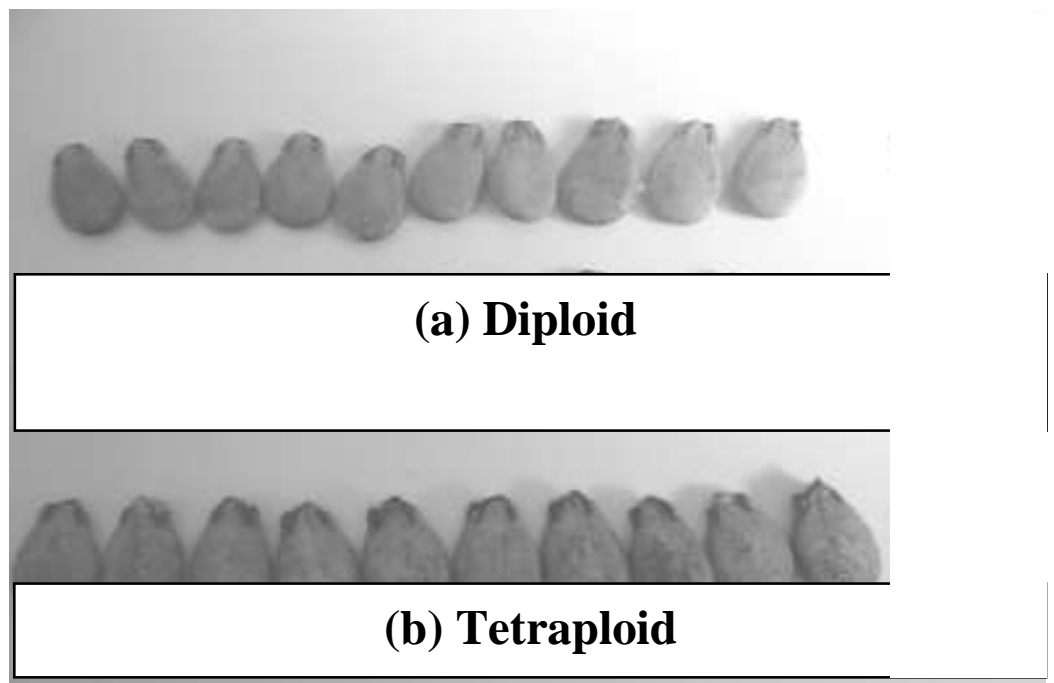

Fig. (6 B). Seed characters obtained from diploid (a) and tetraploid (b) of watermelon fruits. 


\section{GENERAL CONCLUSION}

The results conclude that the morphological changes in treated watermelon plants were not enough reliable and accurate indicators for identification of tetraploid plants but selection on pollen grain diameter, chloroplast number in guard cells and chromosome number proved to be an effective way to identify the tetraploid plants and these methods are suitable, quick and easy for identifying the ploidy level of watermelon in various stages of the plant development. On the other hand physical characters of flowers were good indicators of plant ploidy in watermelon.

\section{REFERENCES}

1. Abak, K., N. Comlekcioglu , S. Buyikalaca and N. San. 1998. Use of stomatal characteristics to estimate ploidy level of haploid and diploid pepper plants. Tenth Eucarpia meeting Capsicum and eggplant. 7 - 11 September. 1998. Avignon, France, pp: $179-182$.

2. Agayev, Y. M. 2002. New featues in karyotype stuctue and origin of safton (Crocus Sativus L). Cytologia, 67: 245 - 252.

3. Andrus, C. F., V. S. Seshadri and P. C. Grimball. 1971. Production of seedless watermelon. Agric.Res. Sevice, U S D A Tech. Bull. No. 1425.

4. Avery, G. S. and L. Pottorf. 1945. Polyploidy, auxin and nitrogen in green plants. Amer. J. Bot., 32: $669-671$.

5. Bhiravamurty, P. V. and P. Rethy. 1984. Origin and evolution of tetaploid forms with the solanum nigrun L. complex. Proc. Indian Acad. Sci., (plant sci.) 93: 553 560.

6. Cardi, T., Carputo and L. Fruciante. 1992. In vito shoot regeneration and chromosome doubling in $2 x$ and $3 x$ potato clones. Amer. Potato J. 69: $1-12$.

7. Chakraborti, S. P., K.Viyan and B. N. Roy. 1998. In vitro induction of tetraploid in mulberry ( Morus alba L.). Plant Cell report. 17: $799-803$.

8. Compton, M. E. and R. E.Veilleux. 1991. Variation for genetic recombination among tomato plants regenerated from thee tissue culture systems. Genome, 34: $810-817$.

9. Compton M. E., D. J. Gray and G. W. Elmston. 1996. Identification of tetaploid regenerates from cotyledons of diploid watermelon cultured in vitro. Euphytica, 87: $165-172$. 
10. Fassuiotis, G. and B. V. Nelson. 1992. Regeneration of tetraploid muskmelons from cotyledons and their morphological differences from two diploid muskmelon genotypes J. Amer. Soc. Hort. Sci., 117: 863 - 866.

11. Garret, J. J., B. B.Rhodes and Z. Xing-Ping. 1995. Tetraploid watermelon resist fruit blotch organism. Rpt. Cucurbits Genet Crop., 18: 56 - 57.

12. Guimara.L. and H. U. Stotz. 2004. Oxalate production by selerotinia sclerotioum deregulates guard cell during infection. Plant Physiol., 136: 3703 - 3711.

13. Jacobs, J P. and J. I.,Yader. 1989. Polidy levels of transgenic tomato plants determined by chloroplast number. Plant ZZcell Rep. 7: $662-664$.

14. Jaskani, M., S. Kwon and D. H. Kim. 2005. Flow cytometry of DNA content of Colabicine treated watermelon as a ploidy screening method at M1 stage. Pak. J. Bot. 37: $685-696$.

15. Joshi, P. and R. C. Verma. 2004. High frequency production of colchicines induced tetraploids in faba bean ( Vicia faba L.) Cytologica, 69: 141 - 147.

16. Kihara, H. 1951. Tetraploid watermelom. J. Am. Soc. Hort. Sci., 58: $217-230$.

17. Lower R.L., K.W. Johnson. 1969. Observation on sterility of induced autuitetraploid watermelons. J Am. Soc. Hort. Sci., 94: 367 - 369.

18. Marr, C. and K. L. B. Gast. 1991. Reaction of consumers in a farmers market to prices for seedlings watermelon and rating of eating quality. Hort.Technol., 1: 105 $-106$.

19. McCuistion, G .and G. W. Elmstron. 1993. Identifying polyploids of various cucurbits. Proc. Fla. St. Hort. Soc., 106: 155 - 157.

20. Mohr, H. C. 1986. Watermelon breeding. In: Bassett, M(ed) Breeding Vegetable Crops (pp 37 - 66). AVI publ.Co. Westport, CT.

21. Montalvo, A.E. and J. Esnard. 1994. Reaction of ten cultivars of watermelon (citrullus Lanatus) to a Puerto ican population of Meloidogyne incognita. J. Nematology, 26: 640 - 643 .

22. Muhammed, J., W. Jaskani and Daf Kin. 2005. Flow cytomety of DNA content of colchicines treated watermelon as a ploidy screening method at MI stage. Pak. J. Bot. 37(3): $685-696$.

23. Oiama, I. and N. Okudai. 1986. Production of colchicines - induced autotetraploid plants through micrografting in moneoembryonic citrus cultivars. Japan J. Breed. 36: $371-376$. 
24. Perm D., K. Gupta and A. Aghihotri. 2004. Development of an efficient high frequency microspore embryo induction and doubled haploid generation system for Indian mustard (Brassica juncea). New direction for a divers planet. Proceeding of the 4Th International Crop Science Congress, Brisbane, Austalia, 26 Sep- 1 Oct. 2004.

25. Sanford, J. C. 1983. Ploidy manipulations. In ' method in fruit breeding ' Moore, J.N. and J. Janick (eds), Purdue University Press, Indian. 100 - 123.

26. Tulany, E. and M. Unal. 2010. Production of colchicines induced tetraploids in Vicia villosa roth. Caryologia, 63(3): $292-303$.

27. Wan Y., JE. Petolino and JM. Widholm. 1989. Efficient production of doubled haploid plants through colchicines treatment of anther derived maize callus. Theor. Appl Genet; 77: $889-892$.

28. Zamani I., G. Kovaces and Couli Vavdinoudi. 2000. Regeneation of fertile doubled haploid plants from colchicines supplemented media in wheat anther cultue. Plant Breed., 119: $461-465$. 


\section{إنتاج البطيخ الرياعى}

\section{منى عبد الونيس محمد اسامة عبد المنعم الزينى عرفه امام عرفه \\ أقفام بحوث الخضر - معرة بحوث البساتين- مركز البحوث الزراعيه - الدقى - جيزه - مصر}

إنه من الضرورى إستخدام النباتات الرباعيه للحصول على ثمار خالية من البذور • ومن أجل

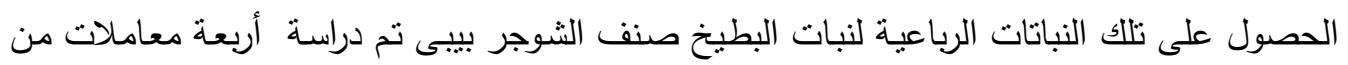
الكولشسين لمعرفة أفضل المعاملات التى يمكن أن تؤدى الى الحصول على نباتات رباعية وكانت تلكاتك

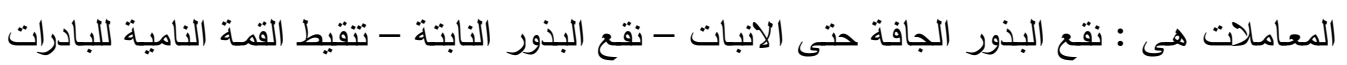

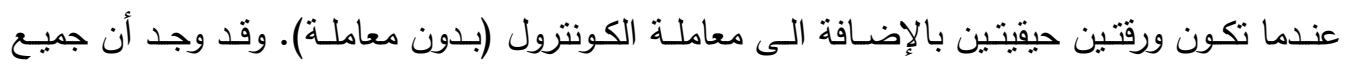

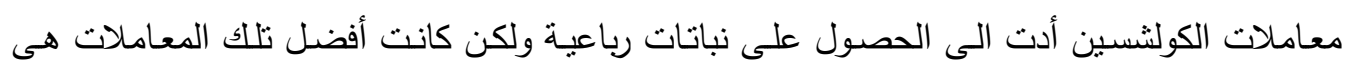

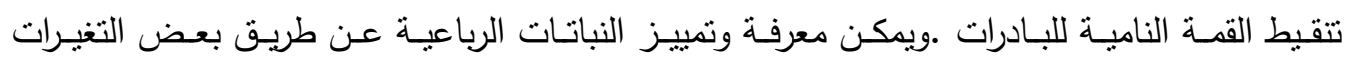

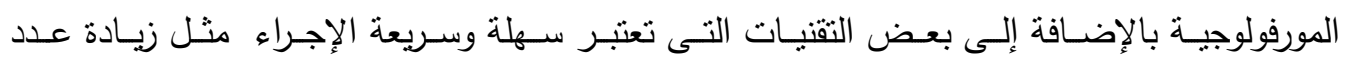

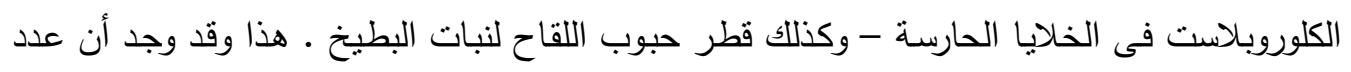

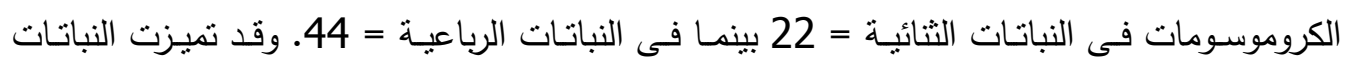

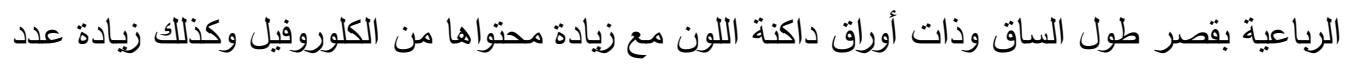

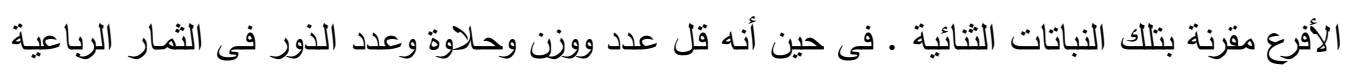

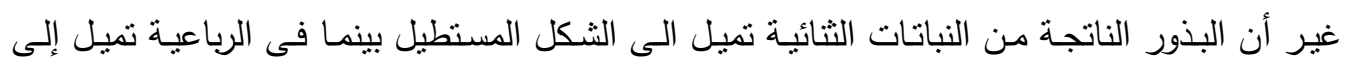
الثكل المستدير • 